\title{
CHANGES IN MICROBIAL INTESTINE FLORA OF BROWN TROUT (SALMO TRUTTA FARIO) FED WITH PREBIOTIC ADDED FEEDS
}

\author{
Hurrem Yumuk Arslan ${ }^{1 *}$, Gonca Alak ${ }^{2}$, Telat Yanık ${ }^{2}$ \\ ${ }^{1}$ Department of Seafood Processing, Faculty of Fisheries, Ataturk University, Erzurum, Turkey \\ ${ }^{2}$ Department of Aquaculture, Fisheries Faculty, Ataturk University, Erzurum, Turkey
}

Current Trends in

Natural Sciences

\begin{abstract}
In this research, Brown trout (Salmo trutta fario L., 1758) with $100 \pm 15 \mathrm{~g}$ from the fish production center of Aquaculture department of Fisheries Faculty at Ataturk university was used. The effects of addition of prebiotic (0 \% prebiotic as control and $0.1 \%$ prebiotic) to the fish diets was determined from a-90 days of feeding trial (Experiment 1) with 4 replications $(2 \times 4=8$ tanks). Fish were distributed randomly to each group of tanks including 40 fish each. Fish were fed with experimental diets twice a day at $10 \pm 1{ }^{\circ} \mathrm{C}$ water temperature. In the experiment treatment vs time interaction was investigated by taking samples from intestine for determination of intestinal bacterial flora and body proximate composition at 0, 30, 60 and 90 . days.

Feeding fish with prebiotic showed that there were significant changes in the number of all bacteria counted from intestinal flora and percentages of chemical composition from fish fillets ( $p<0.05)$.
\end{abstract}

Keywords: Brown trout, chemical composition, intestinal flora, prebiotic.

\section{INTRODUCTION}

In healthy food production due to adding natural additives, research has been focused on the effects of prebiotics (Genç et al, 2011; Alak and Hisar 2012). Probiotics promotes useful microflora in intestines and helps digestion to be regularly and healthy, increases mineral absorption, strengthens immune system. Prebiotics cannot be broken by digestive enzymes of animal. They help host selectively by increasing natural microflora in intestine or growth and metabolic activity of natural bacteria species (probiotics) (Așan and Özcan 2006). Commonly used probiotics are fructooligosaccarides and mannooligosaccharides. Glukooligosaccarides, lactose, lactitol, maltooligosaccarides, sucrose, trans-galaktooligosaccarides are also used as prebiotics (Patterson and Burkholder 2003). Commonly used prebiotics in aquaculture production are mannooligosaccharide (MOS), fruktooligosaccaride (FOS), trans-galaktooligosaccardie (TOS) and Inuline, as fructose derivative (Vulevic et al. 2004; Alak 2011). Inulin is a very common source of polyfructan carbohydrate, which connects fructose molecules $(n \sim 35)$ by $\beta-(2 \rightarrow 1)$ bonds and sucrose molecules in the end (Edelman and Jefford 1964; Aşan Özüsağlam 2009). Indigested inulin in intestines passes to colon and being metabolized there by bacteria. They support lactate formation besides of providing energy for production of short chain fatty acids during anaerobic fermentation (Jenkins et al.1999). 
In aquaculture production, although there are many researches dealing with the effects of prebiotic on growth and health, very few studies focused on the inulin from this respect. Therefore, the aim is determination of the effects of feeding with prebiotic (inulin) on intestine flora (total aerobic mesophilic bacteria, psychrotrophic bacteria, lactic acid bacteria, Pseudomonas and Enterobacteriaceae) and chemical composition (moisture, crude protein, fat, and ash) in brown trout (Salmo trutta fario).

\section{MATERIALS AND METHODS}

Brown trout (Salmo trutta fario L., 1758) with $100 \pm 15$ g mean weight was provided from the research and extension center of Ataturk University used in the study.

A commercial feed (Black sea Feed - Sinop) including 45\% crude protein, 20\% fat, 3\% cellulose, $10 \%$ moisture, $10 \%$ ash and $1 \%$ calcium with a $4801 \mathrm{kcal} / \mathrm{kg}$ total energy value is used during the study. The commercial feed was grounded first and 1\%o commercial prebiotic was added (Orafti® GR) to produce experimental feeds. Experimental feed samples were dried in lyophilizer and stored at refrigerator during the feeding experiment.

\section{DESIGN OF THE EXPERIMENT}

A total of 320 fish with $100 \pm 15 \mathrm{~g}$ mean weight was randomly replaced into 8 tanks and fed with experimental and control feeds for 90 days. The feeding experiment was designed as $4 \times 4 \times 2$ completely randomized design. Four sampling time at 0,30,60 and 90th days and two treatment groups (control and 1\%o prebiotic) with four replicates. Fish were kept at $10 \pm 1^{\circ} \mathrm{C}$ and fed twice a day. Amount of feed was calculated based on the percentage of live weight. Samples from intestines were collected at 0,30,60 and 90th days in order to determine amount of bacterial flora.

\section{CHEMICAL ANALYZES}

At initial and end of the feeding experiment, fish fillets were sampled and subjected to proximate analyzes (crude protein, fat, total dry matter and crude ash) (Gökalp et al, 2001; Alak 2011).

Fillets kept at at cold storage were subject to TVB-N, TBARS and $\mathrm{pH}$ analyzes at $0,3,6,9$ and 12th days of the experiment (Aras Hisar 2002; Alak 2011). Kjeldal method for crude protein analysis was used. Total nitrogen was multiplied by 6.25 to calculate.

\section{MICROBIAL ANALYZES}

Total aerobic mesophilic bacteria, psychrotrophic bacteria, lactic acid bacteria, Pseudomonas and Enterobacteriaceae analyzes were done from dilutions of intestine homogenates at 0, 30, 60 and 90. days of the experiment according to Alak and Hisar (2012). Microbial analyzes from cold stored fillets were done for each bacteria group (total aerobic mesophilic, psychrotrophic, lactic acid, Pseudomonas and Enterobacteriaceae). Microbiological growth mediums (PCA, MRS, CFC and VRBD) were used for counting bacteria colonies (Alak et al., 2010).

\section{STATISTICAL ANALYZES}

Data determined from the present study were subject to variance analysis followed by a multi comparison Duncan test at alpha 0.05 by using SPSS software. 


\section{RESULTS AND DISCUSSIONS}

During the feeding fish with inuline for 90 days, fish intestines were sampled and 0, 30, 60 and 90th days and bacteria count was determined. Total aerobic mesophilic bacteria count from intestine samples of control treatment group is presented at Table 1.

Table 1. Total mesophilic bacteria count determined from brown trout intestines (log CFU/g)

\begin{tabular}{|l|l|l|l|l|}
\hline & & Day & & \\
\hline Groups & $\mathbf{0}$ & $\mathbf{3 0}$ & $\mathbf{6 0}$ & $\mathbf{9 0}$ \\
\hline Control & $3.75 \pm 0.39^{\mathrm{a}}$ & $4.70 \pm 0.88^{\mathrm{b}}$ & $3.00 \pm 0.00^{\mathrm{a}}$ & $3.98 \pm 0.64^{\mathrm{b}}$ \\
\hline $\mathbf{1 \% o}$ Inulin & $3.75 \pm 0.39^{\mathrm{a}}$ & $6.70 \pm 0.48^{\mathrm{a}}$ & $3.00 \pm 0.00^{\mathrm{a}}$ & $4.78 \pm 0.27^{\mathrm{a}}$ \\
\hline
\end{tabular}

a, b: means with same superscripts are not different in same column at alpha 0.05 .

From Table 1, it can be seen that aerobic mesophilic bacteria count was $3.75 \pm 0.39(\log \mathrm{CFU} / \mathrm{g})$ at starting of feeding experiment. It increased at day of 30 and reduced again at day of 60 again in both groups. The differences between treatment and control group with respect to mesophilic bacteria count were significant $(\mathrm{p}<0.05)$ during the study. Similar results were reported by Ringo and Olsen (1999).

Total psychrotrophic bacteria count determined from intestines of brown trout fed on different feeds groups (control and prebiotic) is presented at Table 2.

Table 2. Total psychrotrophic bacteria count determined from brown trout intestines (log CFU/g)

\begin{tabular}{|l|l|l|l|l|}
\hline & & Day & & \\
\hline Groups & $\mathbf{0}$ & $\mathbf{3 0}$ & $\mathbf{6 0}$ & $\mathbf{9 0}$ \\
\hline Control & $5.10 \pm 0.33^{\mathrm{a}}$ & $4.78 \pm 0.43^{\mathrm{b}}$ & $4.42 \pm 0.97^{\mathrm{b}}$ & $4.41 \pm 0.55^{\mathrm{b}}$ \\
\hline $\mathbf{1 \% o}$ Inulin & $5.10 \pm 0.33^{\mathrm{a}}$ & $4.88 \pm 0.24^{\mathrm{a}}$ & $4.65 \pm 0.47^{\mathrm{a}}$ & $6.45 \pm 0.84^{\mathrm{a}}$ \\
\hline
\end{tabular}

a, b, c, d: means with same superscripts are not different in same column at alpha 0.05.

Psychrotrophic bacteria count was $5.10 \pm 0.33 \mathrm{CFU} / \mathrm{g}$ in both groups. At the end of the study, it can be seen that the number of the psychrotrophic count was reducing slightly in control group, but increasing in the treatment group. The differences between treatment and control group with respect to psychrotrophic bacteria count were significant $(\mathrm{p}<0.05)$ during the study.

Reza (2009) reported that there was a significant increase in terms of psychrotrophic bacteria count after the first 4 weeks of feeding with $2 \%$ inulin in sturgeon and it was maximum from the $1 \%$ inulin group at the last 4 weeks of the study. Alak and Hisar (2012) found that amount of total aerobic mesophilic bacteria count had significant effect on psychrotrophic bacteria count in rainbow trout fed with probitic or prebiotic added feeds. They concluded that the reason for this increase might be fish species at rainbow trout was a cold water one. Karimzadeh et al. (2013) reported that gram positive bacteria count was significantly increasing by adding $1 \mathrm{~g} / \mathrm{kg}$ immunogenic [MOS $(18 \%)+\beta$-glucan $(30 \%)]$ to fish feeds.

Total lactic acid bacteria count from intestine samples of control treatment group is presented at Table 3. 
Current Trends in Natural Sciences

Vol. 10, Issue 19, pp. 181-186, 2021

https://doi.org/10.47068/ctns.2021.v10i19.024

Current Trends in Natural Sciences (on-line)

Table 3. Total lactic acid bacteria count determined from brown trout intestines (log CFU/g)

\begin{tabular}{|l|l|l|l|l|}
\hline & & Day & & \\
\hline Groups & $\mathbf{0}$ & $\mathbf{3 0}$ & $\mathbf{6 0}$ & $\mathbf{9 0}$ \\
\hline Control & $2.35 \pm 0.09^{\mathrm{a}}$ & $3.46 \pm 0.45^{\mathrm{a}}$ & $3.40 \pm 0.56^{\mathrm{a}}$ & $2.80 \pm 0.28^{\mathrm{a}}$ \\
\hline $\mathbf{1 \%}$ Inuline & $2.35 \pm 0.09^{\mathrm{a}}$ & $2.86 \pm 0.15^{\mathrm{b}}$ & $2.88 \pm 0.58^{\mathrm{b}}$ & $2.65 \pm 0.49^{\mathrm{b}}$ \\
\hline
\end{tabular}

a, b, c, d: means with same superscripts are not different in same column at alpha 0.05.

At the initial of feeding lactic acid bacteria count was $2.35 \pm 0.09^{\mathrm{b}}$ in both groups. Maximum value was $3.46 \pm 0.45 \mathrm{CFU} / \mathrm{g}$ in 30 th day of experiment in control group. There was difference $(\mathrm{p}<0.05)$ between control and Inulin group at the end of the experiment. In accordance with the findings of the present study, Luna Gonzales et al. (2012) reported that Inulin did not affect density of lactic acid bacteria

Pseudomonas count from intestine samples of control and treatment group is presented at Table 4 .

Table 4. Pseudomonas count determined from brown trout intestines $(\log C F U / g)$

\begin{tabular}{|l|l|l|l|l|}
\hline & & Day & & \\
\hline Groups & $\mathbf{0}$ & $\mathbf{3 0}$ & $\mathbf{6 0}$ & $\mathbf{9 0}$ \\
\hline Control & $2.00 \pm 0.00^{\mathrm{a}}$ & $4.44 \pm 0.24^{\mathrm{b}}$ & $4.75 \pm 0.35^{\mathrm{b}}$ & $3.47 \pm 0.00^{\mathrm{b}}$ \\
\hline $\mathbf{1 \% o}$ Inuline & $2.00 \pm 0.00^{\mathrm{a}}$ & $4.71 \pm 0.24^{\mathrm{a}}$ & $5.02 \pm 0.00^{\mathrm{a}}$ & $3.98 \pm 0.22^{\mathrm{a}}$ \\
\hline
\end{tabular}

a, b, c, d: means with same superscripts are not different in same column at alpha 0.05.

At initial of the feeding experiment, Pseudomonas count was $2.00 \pm 0.00(\log \mathrm{CFU} / \mathrm{g})$ in inulin and control groups. Differences were significant starting from 30 days among in both groups. It was maximum at 60th day in inulin group. There were significant differences $(p<0.05)$ between the groups with respect to Pseudomonas count during the study. In another study, Similar to our findings, Ringo and Strom (1994) reported dominance of Pseudomonas bacteria from a feeding study. In some other reports it is highlighted that microorganism number may depend on species, feedings style and living environment. It is known that gram-negative bacteria are found predominantly in natural flora of predators living in cold waters.

Enterobacteriaceae count from intestine samples of control and treatment group is presented at Table 5.

Table 5. Enterobacteriaceae count determined from brown trout intestines $(\log \mathrm{CFU} / \mathrm{g})$

\begin{tabular}{|l|l|l|l|l|}
\hline & & Day & & \\
\hline Groups & $\mathbf{0}$ & $\mathbf{3 0}$ & $\mathbf{6 0}$ & $\mathbf{9 0}$ \\
\hline Control & $5.15 \pm 0.14^{\mathrm{a}}$ & $3.13 \pm 0.31^{\mathrm{a}}$ & $2.45 \pm 0.21^{\mathrm{b}}$ & $3.00 \pm 0.00^{\mathrm{b}}$ \\
\hline $\mathbf{1 \% o}$ Inuline & $5.15 \pm 0.14^{\mathrm{a}}$ & $3.13 \pm 0.51^{\mathrm{a}}$ & $3.16 \pm 0.00^{\mathrm{a}}$ & $4.00 \pm 0.00^{\mathrm{a}}$ \\
\hline
\end{tabular}

a, b, c, d: means with same superscripts are not different in same column at alpha 0.05.

At initial of the feeding experiment, Enterobacteriaceae count was $5.15 \pm 0.14^{\mathrm{a}}(\log \mathrm{CFU} / \mathrm{g})$ in inuline and control groups. Number of Enterobacteriaceae reduced till to the end of the study. Differences were significant starting from 30 days among in both groups. It was minimum at 60th 
day in control group. There were significant differences $(\mathrm{p}<0.05)$ between the groups with respect to Enterobacteriaceae count during the study.

We thing reduction in e Enterobacteriaceae count might be due to increase of gram-positive bacteria. Similarly, Alak (2011) reported that there was a reduction in Enterobacteriaceae count due to increase of lactic acid bacteria in intestine flora of trout fed with prebiotic added feeds.

\section{CHEMICAL ANALYZES}

Crude protein, total fat, moisture and ash of brown trout fillets were analyzed at the start of feeding (day 0) and at the end of the research period (day 90) and results are presented in Table 6.

Table 6. Crude protein, total fat, moisture and ash of brown trout fillets (\%)

\begin{tabular}{|l|l|l|l|l|l|}
\hline Groups & $\begin{array}{l}\text { Sampling } \\
\text { time (day) }\end{array}$ & Moisture & Crude Protein & Ash & Total fat \\
\hline Control & $\mathbf{0}$ & $76.95 \pm 0.23$ & $18.36 \pm 0.02$ & $1.24 \pm 0.18$ & $2.52 \pm 0.01$ \\
\hline Control & $\mathbf{9 0}$ & $76.40 \pm 1.35^{\mathrm{b}}$ & $18.82 \pm 0.01^{\mathrm{a}}$ & $1.37 \pm 0.12^{\mathrm{a}}$ & $2.19 \pm 0.10^{\mathrm{b}}$ \\
\hline $\mathbf{1} \%$ Inuline & $\mathbf{9 0}$ & $77.35 \pm 0.44^{\mathrm{a}}$ & $18.28 \pm 0.01^{\mathrm{b}}$ & $1.28 \pm 0.01^{\mathrm{b}}$ & $2.82 \pm 0.24^{\mathrm{a}}$ \\
\hline
\end{tabular}

a, b, c, d: means with same superscripts are not different in same column at alpha 0.05.

At the beginning of feeding, moisture percent value was determined as $76.95 \pm 0.23$. While this value decreased in the control group during the feeding period $(76.40 \pm 1.35)$, it increased in the group fed with 1 inuline content $(77.35 \pm 0.44)$. At the beginning of feeding, the raw ash value of $1.24 \pm 0.18$ was determined as $1.28 \pm 0.01$ in the control group and $1.37 \pm 0.12$ in the control group. Crude fat values of the groups were determined as $2.52 \pm 0.01$ at the beginning of the feeding and at the end of the study, the value of the crude oil decreased in the control group at the level of $2.19 \pm$ 1.02. It was determined as $82 \pm 0.24$. The initial crude protein values of the groups increased from $18.36 \pm 0,02$ in the control group and reached $18.82 \pm 0.01$. Similar to our results, it was reported that addition of prebiotic to feeds decreased the crude protein content and the increased total fat value (Reza 2009; Ortiz et al. 2013; Wu et al. 2013).

\section{CONCLUSION}

In aquaculture, it is of great importance to determine the bacterial load of fish in order to prevent economic losses. Adding prebiotic did not differ significantly microbial intestine composition of fish. The results of the study showed that the natural bacterial flora of fish was within normal limits. Further studies are needed for shelf life of fish fillets.

\section{ACKNOWLEDGMENT}

This research is a part of a scientific research project (BAP) with 2013/123 number.

\section{REFERENCES}

Alak, G. (2011). Probiyotik ve Prebiyotiklerin Gökkuşağı Alabalığı (Oncorhynchus mykiss) Bağırsak Florası ile Filetolarının Bazı Fiziksel, Kimyasal ve Mikrobiyolojik Özelliklerine Etkileri [Effects of Probiotics and Prebiotics on Some Physical, Chemical and Microbiological Properties of Rainbow Trout (Oncorhynchus mykiss) Intestinal Flora and Fillet]. Atatürk Üniversitesi Fen Bilimnleri Enstitüsü Doktora Tezi. Erzurum.

Alak, G., Aras Hisar, Ş., Hisar, O., Kaban, G. \& Kaya, M. (2010). Microbiological and chemical properties of bonito fish (Sarda sarda) fillets packaged with chitosan film, modified atmosphere and vacuum. Kafkas Univ. Vet. Fak. Derg., 16 (A), 73-80. 


\section{Current Trends in Natural Sciences}

Vol. 10, Issue 19, pp. 181-186, 2021

https://doi.org/10.47068/ctns.2021.v10i19.024

Aras Hisar, Ş. (2002). Modifiye Atmosferde Ambalajlamanın Gökkuşağı Alabalığı (Oncorhynchus mykiss) Filetolarının Fiziksel, Kimyasal ve Mikrobiyolojik Özelliklerine Etkisi [Effect of Packaging in Modified Atmosphere on Physical, Chemical and Microbiological Properties of Rainbow Trout (Oncorhynchus mykiss) Fillet]. Atatürk Üniversitesi Fen Bilimnleri Enstitüsü Doktora Tezi. Erzurum.

Aşan Özüsağlam, M. (2009). İnülinaz enziminin önemi [Importance of inulinase enzyme]. Anadolu Üniversitesi Bilim ve Teknoloji Dergisi, 10 (2), 327-334.

Edelman, J. \& Jefford, T.G. (1964). The metabilism of fructose polymers in plants. 4. Beta fructofuranosidases of tubers of Helianthus tuberosus. L. Biochem. J., 93, 148-161.

Genç, E., Genç, M. A., Aktaş, M., Bircan Yıldırım, Y. \& İkizdoğan, A.T. (2011). Su ürünleri yetiştiriciliğinde mannanoligosakkarit (MOS) kullanımı üzerine türkiye'de farkındalık yaratma [Raising awareness in Turkey on the use of mannanoligosaccharides (MOS) in aquaculture]. Eğirdir Su Ürünleri Fakültesi Dergisi, 7 (1), 18-24.

Gökalp, H.Y., Kaya, M., Tülek, Y. \& Zorba, Ö. (2001). Et ürünlerinde kalite kontrolü ve laboratuvar uygulama klavuzu (4. Bask1). Atatürk Üniv. Yayın No:751, Zir. Fak. Yay. No:318, Ders Kitapları Serisi No: 69, Ziraat Fak. Ofset Tesisi, Erzurum.

Jenkins, D.J.A., Kendal, C.W.C. \& Vuksan, V. (1999). Inulin, oligofructose and intestinal function. J. Nutr., Suppl., 129, 1431-1433.

Karimzadeh, S., Keramat-Amirkolaie, A. \& Esmaeili-Molla, A. (2013). Effects of different levels of 1mmunogen on growth performance, intestinal bacteria colonization and survival rate in Rutilus kutum Larvae. World Journal of Fish and Marine Sciences, 5 (6), 664-669.

Luna Gonzalez, A., Almaraz Salas, J.C., Fierro Coronado, J.A., Flores Miranda, M.D. C., Gonzalez Ocampo, H.A. \& Pereza-Gomez, V. (2012). The prebiotic inulin increases the phenoloxidase activity and reduces the prevalence of WSSV in whiteleg shrimp (Litopenaeus vannamei) cultured under laboratory conditions. Aquaculture, $362-$ $363,28-32$.

Olsen, R. E., Myklebust, R., Kryvi, H., Mayhew, T.M. \& Ringo, E. (2001). Damaging effect of dietary inulin on intestinal enterocytes in Arctic charr (Salvelinus alpinus L.). Aquac. Res., 32, 931-934.

Ortiz, L. T., Rebole, A., Velasca, S., Rodriguez, M.I., Trevino, J., Tejedor, J.I. \& Alzueta, C. (2013). Effects of inulin and fructooligosaccharide on growth performance, body chemical composition and intestinal microbiota of farmed rainbow trout (Oncorhynchus mykiss). Aquaculture Nutrition, 19, 475-482.

Patterson, J. A. \& Burkholder, K. M. (2003). Application of prebiotics and probiotics in poultry production. Poultry Science, 82 (4), 627-631.

Reza, A., Abdolmajid, H., Abbas, M. \&Abdolmohammad, A.K. (2009). Effect of dietary prebiotic inulin on growth performance, intestinal microflora, body composition and hematological parameters of juvenile beluga, (Huso hoso, L. 1758). J. World Aquaculture Soc., 40, 771-779.

Ringo, E. \& Olsen, R.E. (1999). The effect of diet on aerobic bacterial flora associated with intestine of Arctic charr (Salvelinus alpinus L.). Journal of Applied Microbiology, 86 (1), 22-28.

Ringo, E. \& Strom, E. (1994). Microflora of arctie charr, Salvelinus alpinus (L.): gastrointestinal microflora of freeliving fish and effect of diet and salinity pn intestinal microflora. Aquaculture and Fisheries Management, 25 (6), 623-629.

Vulevic, J., Rastall, R.A. \& Gibson, G.R. (2004). Developing a quantitative approach for determining the invitro prebiotic potential of dietary oligosaccharides. FEMS Microbiology Letters., 236, 153-159.

Wu, Y., Liu, W.B., Li, H.Y., Xu, W.N., He, J.X., Li, X.F. \& J1ang, G.Z. (2013). Effectsof dietary supplementation of fructooligosaccharide on growth performance, body composition, intestinal enzymes activities and histology of blunt snout bream (Megalobrama amblycephola) fingerlings. Aquaculture Nutrition, 19, 886-894. 